\title{
Ejemplos de utilización de la enseñanza problémica en la matemática
}

\author{
Hernández Camacho, Reinaldo; Reyna Hernández, Mayté
}

\section{Resumen}

La enseñanza problémica es considerada por muchos pedagogos como la forma de proceder más eficiente que puede adoptar el profesor durante el proceso de enseñanza-aprendizaje con sus estudiantes. En este trabajo, además de presentarse los conceptos básicos elementales relacionados con esta forma de enseñanza, se ha querido mostrar, también, dos ejemplos de utilización de la enseñanza problémica en la introducción de un nuevo contenido matemático. En particular, uno de los contenidos que se ha elegido corresponde a la Enseñanza de la Matemática en el nivel universitario, donde, hemos tenido la experiencia personal de aplicarlo con los estudiantes de la Universidad de Matanzas, Cuba.

Palabras claves: enseñanza problémica, problema, pregunta problémica, heurística.

\section{Summary}

\section{Examples of use of the conceptualized in mathematics teaching}

The teaching problem is considered by many educators as the most efficient way of proceeding that can take the teacher during the teaching-learning process with their students. In this paper, in addition to presenting the basic concepts related to this form of teaching, we have tried to show, also, two examples of the use of teaching problem in the introduction of a new mathematical content. In particular, one of the contents you have chosen corresponds to the Teaching of Mathematics at the university level, where, we have had the personal experience of applying it with the students of the University of Matanzas, Cuba.

Keywords: teaching problemic, problem, asked problemic, heuristics. 